\title{
THE EFFECT OF rGH ADDITION ON ARTIFICIAL FEED ON HOVEN'S CARP GROWTH, Leptobarbus hoevenii (Bleker, 1851)
}

\author{
Nur Selawati *1, Indra Gumay Yudha, dan Deny Sapto Chondro Utomo*2
}

\begin{abstract}
Hoven's carp is one of the potential fish in Indonesia to be developed. But due to its slow growth, making people not cultivating it. This research aimed to study the effect of using rGH and determine the best dosage on growth of hoven's carp. Hoven's carp used were $70-90 \mathrm{~mm}$ in size and 5 - $6 \mathrm{~g}$ in weight 4 months old. Hoven's carp used are 10 fish in each pond This study used a completely randomized design with 4 treatments and 3 replications. The treatment was $A$ (without administration of $\mathrm{rGH}$ ), B (administration of $\mathrm{rGH} 1 \mathrm{mg} / \mathrm{kg}$ of feed), $C$ (administration of $\mathrm{rGH} 2 \mathrm{mg} / \mathrm{kg}$ of feed), and D (administration of rGH $3 \mathrm{mg} / \mathrm{kg}$ of feed). Parameters observed consisted of growth absolute length, the growth of absolute weight, SR, FCR, and protein retention. The results showed that the effect on hoven's carp growth of rGH and best dose in this study is in treatment $B$ (administration of $\mathrm{rGH} 2 \mathrm{mg} / \mathrm{kg}$ offeed).
\end{abstract}

Kata kunci: administration, dose, treatment, parameters

\section{Pendahuluan}

Ikan jelawat (Leptobarbus hoevenii) merupakan salah satu ikan asli Indonesia yang memiliki potensi ekonomis tinggi. Ikan jelawat memiliki harga jual sebesar Rp. $60.000,00 / \mathrm{kg}$ pada bulan Agustus 2018 di daerah Kalimantan Tengah. Beberapa negara seperti Malaysia dan Brunei bahkan mengimpor ikan jelawat untuk memenuhi kebutuhan pasar. Hal ini menjadikan ikan jelawat sebagai komoditas yang potensial untuk dikembangkan (Rusliadi et al., 2015).

Ikan jelawat mudah dibudidayakan akan tetapi banyak masyarakat yang enggan membudidayakan ikan ini. Masyarakat lebih memilih jenis ikan lain, seperti ikan lele, ikan nila, ikan mas, dan ikan lainnya karena masa pertumbuhan dan panen cepat sehingga dinilai lebih menguntungkan untuk dibudidayakan. Adapun ikan jelawat dipanen pada umur 6 - 10 bulan (Abrar et al., 2015).

Dalam usaha pembesaran ikan jelawat, makanan merupakan salah satu faktor penentu keberhasil-an pertumbuhan dan perkembangan individu yang dipelihara. Pertumbuhan ikan jelawat terbaik yaitu pada pemberian pakan dengan kandungan protein $38 \%$. Pada tingkat kebutuhan

\footnotetext{
${ }^{1}$ E-mail: nurselawati1010@ gmail.com

2 Jurusan Perikanan dan Kelautan, Fakultas Pertanian, Universitas Lampung

Jl. Prof. S. Brodjonegoro No.1 Gedong Meneng Bandar Lampung, 35145
} 
protein tersebut nilai FCR yang didapat sebesar 1,70 (Farahiyah et al., 2017). Penggunaan pakan yang digunakan saat pembesaran ikan jelawat sampai masa panen cukup banyak sehingga biaya yang dikeluarkan juga tinggi. Salah satu upaya untuk meningkatkan laju pertumbuhan dan mempersingkat masa budidaya yaitu dengan penggunaan hormon pertumbuhan.

Hormon pertumbuhan memainkan peranan yang penting dalam mengatur banyak aspek fisiologi, termasuk pertumbuhan (Cavari et al., 1993), metabolisme (Rousseau dan Dufour, 2007), osmoregulasi (Sakamoto et al., 1997), fungsi kekebalan tubuh (Yada et al., 1999), dan reproduksi (McLean et al., 1993). Hormon pertumbuhan di-produksi di kelenjar pituitari, akan tetapi jumlahnya terbatas di dalam tubuh ikan. Untuk mengatasi keterbatasan hormon pertumbuhan dalam tubuh ikan, dapat digunakan recombinan growth hormone (rGH) (Lesmana, 2010).

Recombinan growth hormone (rGH) merupakan hormon pertumbuhan yang terdapat di dalam tubuh ikan yang kemudian ditransformasikan pada bakteri. Pemberian rGH dapat dilakukan melalui beberapa metode, seperti dengan penyuntikan, secara oral melalui pakan, dan perendaman. Aplikasi rGH melalui pemberian pakan dan perendaman merupakan metode yang paling aplikatif untuk diterapkan dalam skala besar (Moriyama dan Hiroshi, 1990). Pengaplikasian hormon pertumbuhan secara oral telah banyak dibuktikan mampu meningkatkan pertumbuhan beberapa jenis ikan seperti ikan gurame (Putra et al., 2016), ikan nila larasati (Ihsanudin et al., 2014), dan ikan botia (Permana et al., 2015). Berdasarkan hal tersebut, penelitian mengenai pemberian $\mathrm{rGH}$ dengan dosis yang berbeda pada pakan buatan perlu dilakukan untuk mengetahui pengaruhnya terhadap pertumbuhan, keluluhidupan, dan penentuan dosis terbaik pada benih ikan jelawat.

\section{Metode}

\section{Waktu dan Tempat}

Penelitian dilakukan pada bulan Oktober - Desember 2018 selama 70 hari di Laboratorium Budidaya Perikanan, Jurusan Perikanan dan Kelautan, Fakultas Pertanian, Universitas Lampung.

\section{Alat dan Bahan}

Alat yang digunakan pada penelitian ini yaitu kolam terpal sebanyak 6 buah, waring, DO meter, $\mathrm{pH}$ meter, termometer, alat tulis, ember, timbangan digital, kamera, penggaris, spray, dan scoopnet. Bahan yang digunakan dalam penelitian yaitu benih ikan jelawat umur \pm 4 bulan sebanyak 120 ekor dengan ukuran benih berkisar 7-9 cm, recombinan growth hormone ( $\mathrm{rGH})$, pakan komersil, air tawar, telur ayam, dan larutan PBS (Phospat Buffered Saline).

\section{Rancangan Penelitian}

Rancangan penelitian yang digunakan adalah rancangan acak lengkap (RAL) dengan 4 perlakuan yang masing-masing perlakuan terdiri dari 3. Perlakuan yang digunakan yaitu A (tanpa rGH), B (rGH $1 \mathrm{mg} / \mathrm{kg}$ pakan), C (rGH $2 \mathrm{mg} / \mathrm{kg}$ pakan), dan $\mathrm{D}$ (rGH $3 \mathrm{mg} / \mathrm{kg}$ pakan). 


\section{Prosedur Penelitian}

\section{Persiapan Wadah}

Wadah yang digunakan pada penelitian ini adalah kolam terpal berukuran $1,5 \times 1 \times 0,5 \mathrm{~m}^{3}$ sebanyak 6 unit yang kemudian pada masingmasing kolam diberi sekat berupa dua buah waring berukuran $0,75 \times 0,5 \times$ $0,5 \mathrm{~m}^{3}$.

\section{Biota Uji}

Ikan yang digunakan pada penelitian ini adalah benih ikan jelawat yang ukuran panjang dan beratnya sama yang berukuran 70 - 90 $\mathrm{mm}$ dan berat 5 - $6 \mathrm{~g}$ yang berumur \pm 4 bulan dengan padat tebar $60 \mathrm{ekor} / \mathrm{m}^{3}$ yang telah disediakan.

\section{Pencampuran rGH pada Pakan}

rGH ditimbang dengan berat sesuai dengan perlakuan $(1 \mathrm{mg} / \mathrm{kg}$ pakan, $2 \mathrm{mg} / \mathrm{kg}$ pakan, dan $3 \mathrm{mg} / \mathrm{kg}$ pakan). rGH dilarutkan dalam larutan PBS (Phospat Buffered Saline) sebanyak $\pm 2 \mathrm{ml}$ tiap dosis perlakuan yang berfungsi sebagai pengencer, ditambah air $50 \mathrm{ml}$, dan telur ayam sebanyak $20 \mathrm{mg} / \mathrm{kg}$ pakan yang berfungsi sebagai binder. Larutan yang telah tercampur dimasukkan ke dalam sprayer. Pakan disemprot dengan larutan $\mathrm{rGH}$ yang telah dipersiapkan sebelum-nya. Pakan dikeringkan dengan cara dianginanginkan dalam suhu ruangan dan setelah kering pakan dimasukkan ke dalam wadah penyimpanan yang tertutup. Pakan uji yang telah dibuat kemudian diuji coba ke stok benih ikan jelawat yang ada. Hal ini bertujuan untuk mengujikan pakan apakah pakan yang telah dibuat dapat dan mau dimakan oleh ikan.

\section{Pemberian Pakan}

Pemberian pakan dilakukan 3 kali sehari yaitu pada pukul 08.00 WIB, siang pukul 12.00 WIB, dan sore hari pukul 16.00 WIB. Pemberian pakan dilakukan dengan metode pemberian pakan sebesar 5\% dari bobot ikan perhari. Pakan perlakuan diberikan dengan interval waktu 3 hari.

\section{Sampling}

Sampling dilakukan setiap 7 hari sekali untuk mengukur pertumbuhan panjang dan berat tubuh benih ikan jelawat. Benih ikan jelawat yang diukur berjumlah 10 ekor tiap masing-masing perlakuan. Pengukuran kelulushidupan ikan dilakukan pada awal dan akhir penelitian.

\section{Parameter yang Diamati}

Parameter yang akan diamati dalam penelitian ini meliputi pertumbuhan panjang mutlak, pertumbuhan berat mutlak, kelulushidupan (SR), laju konversi pakan (FCR), retensi protein, serta kualitas air yang meliputi $\mathrm{pH}, \mathrm{DO}$, dan suhu.

\section{Pertumbuhan Panjang Mutlak}

Laju pertumbuhan panjang akan diukur dengan menggunakan persamaan Effendie (1997) sebagai berikut:

$$
\mathbf{L}=\mathbf{L t}-\mathbf{L o}
$$

Keterangan :

$\mathrm{L} \quad=$ Pertumbuhan panjang $(\mathrm{mm})$

Lt = Panjang tubuh ikan pada akhir penelitian $(\mathrm{mm})$

Lo = Panjang tubuh ikan pada awal penelitian $(\mathrm{mm})$

\section{Kelulushidupan}


Kelulushidupan diperoleh berdasarkan persamaan yang dikemukakan oleh Effendie (1997) yaitu:

Keterangan :

$$
\mathbf{S R}=\frac{\mathbf{N t}}{\mathrm{No}} \times 100 \%
$$

$\mathrm{SR}=$ Kelulushidupan $(\%)$

$\mathrm{Nt}=$ Jumlah ikan pada akhir penelitian (ekor)

No = Jumlah ikan pada awal penelitian (ekor)

\section{Pertumbuhan Berat Mutlak}

Pertumbuhan bobot total tiap kolam dihitung dengan menggunakan persamaan Effendie (1997) sebagai berikut:

$$
\mathbf{W}=\mathbf{W t}-\mathbf{W o}
$$

Keterangan :

$\mathrm{W}=$ Pertumbuhan berat mutlak $(\mathrm{g})$

$\mathrm{Wt}=$ Berat rata-rata akhir $(\mathrm{g})$

$\mathrm{Wo}=$ Berat rata-rata awal $(\mathrm{g})$

\section{Laju Konversi Pakan (FCR)}

Laju konversi pakan (FCR) dihitung dengan persamaan Effendie (1997) sebagai berikut:

$$
\mathbf{F C R}=\frac{\mathbf{F}}{(\mathbf{W t}+\mathbf{W d}) \mathbf{W o}}
$$

Keterangan:

FCR = Laju konversi pakan

$\mathrm{F} \quad=$ Jumlah pakan yang diberikan selama pemeliharaan (g)

Wo = Berat ikan awal penelitian (g)

$\mathrm{Wt}=$ Berat ikan akhir penelitian $(\mathrm{g})$

$\mathrm{Wd}=$ Bobot ikan yang mati $(\mathrm{g})$

\section{Retensi Protein}

Perhitungan retensi protein (RP) dengan menggunakan persamaan sebagai berikut (Watanabe, 1988):

$$
\mathbf{R P}=\frac{\mathbf{P t}-\mathbf{P o}}{\mathbf{P k}} \times 100 \%
$$

Keterangan :

$\mathrm{RP}=$ Retensi Protein $(\%)$

$\mathrm{Pt}=$ Protein tubuh ikan pada akhir pemeliharaan $(\mathrm{g})$

Po $=$ Protein tubuh ikan pada awal pemeliharaan $(\mathrm{g})$

$\mathrm{Pk}=$ Total protein yang dikonsumsi pada pakan $(\mathrm{g})$

\section{Kualitas air}

Pada penelitian ini parameter kualitas air yang diukur, yaitu suhu, $\mathrm{pH}$, dan DO. Pengukuran dilakukan pada setiap perlakuan dengan frekuensi 7 hari sekali selama penelitian.

\section{Analisis Data}

Data pertumbuhan panjang mutlak, pertumbuhan berat mutlak, kelulushidupan, laju konversi pakan (FCR), dan retensi protein ikan jelawat diuji homogenitas dan normalitasnya. Data yang telah homogen dan normal diolah dengan analisis sidik ragam (Anova) untuk mengetahui pengaruh pemberian hormon pertumbuhan ter-hadap pertumbuhan ikan jelawat. Apa-bila berbeda nyata antar perlakuan maka diuji lanjut dengan uji Duncan pada tingkat kepercayaan 95\%. Adapun kualitas air dianalisis secara deskriptif.

\section{Hasil dan Pembahasan}

Pertumbuhan Panjang Mutlak

Hasil pengamatan setiap

minggunya dapat dilihat pada

Gambar 1 


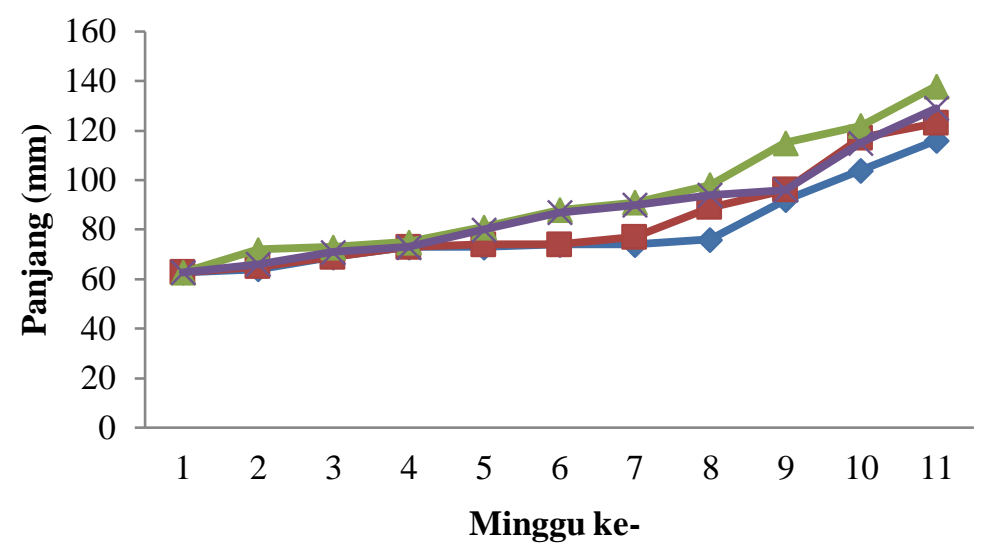

Gambar 1. Grafik perubahan panjang rata-rata individu ikan jelawat pada setiap perlakuan selama penelitian

Dari hasil grafik di atas dapat dilihat panjang ikan jelawat mengalami kenaikan yang cukup signifikan hingga hari ke-70. Adapun hasil pertumbuhan panjang mutlak ikan jelawat dapat dilihat pada Gambar 2.

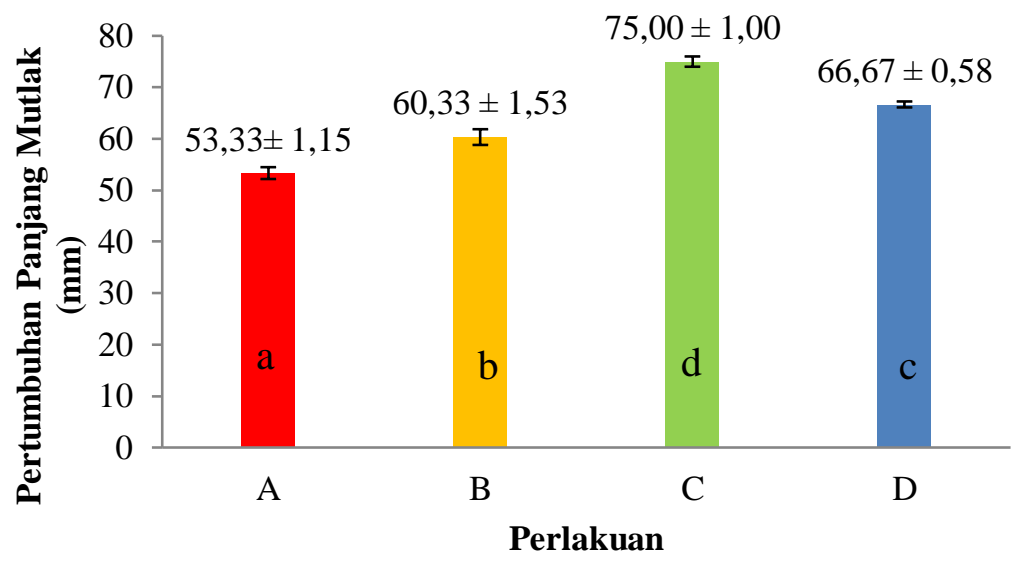

Keterangan: huruf kecil yang sama pada histogram menunjukkan perlakuan tidak berbeda nyata Gambar 2. Pertumbuhan panjang mutlak ikan jelawat

Hasil pengamatan panjang mutlak individu ikan jelawat selama penelitian diketahui panjang mutlak tertinggi terdapat pada perlakuan $\mathrm{C}$ $(75,00 \pm 1,00 \mathrm{~mm})$, kemudian diikuti perlakuan $\mathrm{D}(66,67 \pm 0,58 \mathrm{~mm})$, perlakuan $\mathrm{B}(60,33 \pm 1,53 \mathrm{~mm})$, dan yang terendah pada perlakuan A $(53,33 \pm 1,15 \mathrm{~mm})$. Hasil analisis sidik ragam (Anova) menunjukkan bahwa pem-berian rGH pada ikan jelawat ber-pengaruh nyata terhadap pertumbuhan ikan.

Pertumbuhan panjang ikan jelawat pada pengamatan terakhir menunjukkan bahwa perlakuan $\mathrm{C}$ yang lebih tinggi dikarenakan ikan mampu menyerap nutrisi pada pakan secara optimal. Berdasarkan hasil tersebut juga menunjukkan bahwa rGH yang masuk ke dalam tubuh ikan tersebut diduga merangsang hipotalamus untuk meningkatkan 
kerja GH-RH (hormon pemacu hormon pertumbuhan) diterus-kan ke kelenjar ptuitari yang menghasil-kan hormon pertumbuhan kemudian masuk ke dalam organ dalam tubuh ikan seperti hati, ginjal, otot, tulang, dan organ yang lain sehingga menyebabkan ikan tumbuh lebih cepat. Dosis rendah pada perlakuan B belum dapat merangsang pertumbuhan panjang mutlak secara optimal pada ikan, serta sebaliknya dosis tertinggi pada perlakuan D mengakibatkan rangsangan berlebih atau memiliki sifat antagonis-tik. Hal tersebut mengakibatkan penghambatan sekresi $\mathrm{GH}$ oleh kelenjar, serta secara tidak langsung menghambat kinerja rGH.

\section{Pertumbuhan Berat Mutlak}

Hasil pengamatan berat ikan jelawat setiap minggunya dapat dilihat pada Gambar 3.

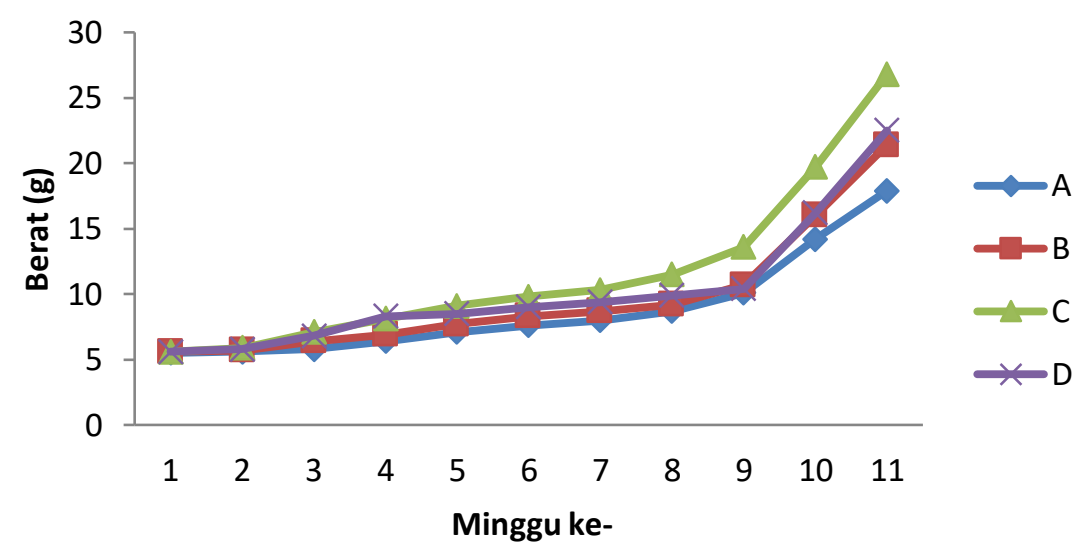

Gambar 3. Grafik perubahan berat rata-rata individu ikan jelawat pada setiap perlakuan selama penelitian

Hasil pengamatan pertumbuhan berat mutlak ikan jelawat untuk lebih jelasnya dapat dilihat pada Gambar 5.

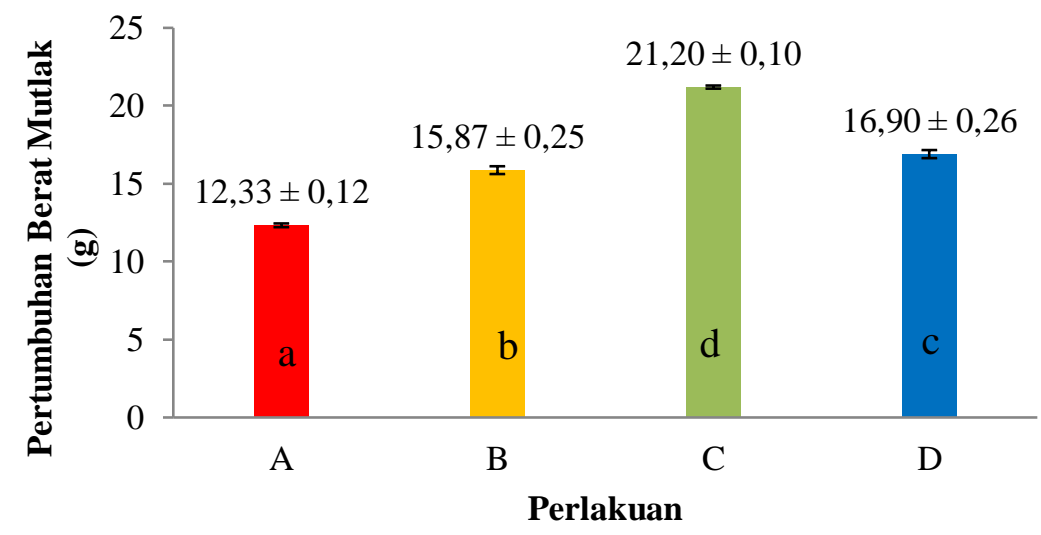

Keterangan: huruf kecil yang sama pada histogram menunjukkan perlakuan tidak berbeda nyata Gambar 4. Pertumbuhan berat mutlak ikan jelawat 
Pertumbuhan berat ikan jelawat mengalami kenaikan pada setiap minggunya (Gambar 3). Pertumbuhan berat mutlak ikan jelawat selama penelitian yaitu berkisar antara 12,33 - 21,20 g (Gambar 4). Perlakuan C memberikan hasil dengan pertumbuhan terbesar yaitu 21,20 \pm $0,10 \mathrm{~g}, \quad$ kemudian diikuti oleh perlakuan $\mathrm{D}(16,90 \pm 0,26 \mathrm{~g})$, perlakuan $\mathrm{B}(15,87 \pm 0,25 \mathrm{~g})$, dan perlakuan A $(12,33 \pm 0,12 \mathrm{~g})$. Hasil analisis sidik ragam (Anova) menunjukkan bahwa pemberian $\mathrm{rGH}$ pada ikan jelawat berpengaruh nyata terhadap pertumbuhan ikan.

Perlakuan C merupakan dosis yang efektif dalam merangsang pertumbuhan berat mutlak ikan jelawat. Hal ini diduga pakan yang dicampur rGH masuk melalui sistem pencernaaan dalam tubuh dan diterima oleh reseptor dalam tubuh sehingga terjadi mekanisme yang mempengaruhi per-tumbuhan berat ikan jelawat. Dosis rendah pada perlakuan B belum dapat merangsang pertumbuhan secara optimal pada ikan, serta sebaliknya dosis tertinggi pada perlakuan D mengakibatkan rangsangan berlebih atau memiliki sifat antagonistik.

\section{Kelulushidupan}

Hasil pengamatan kelulushidupan ikan jelawat yang diperoleh selama penelitian dapat dilihat pada Gambar 5 di bawah ini.

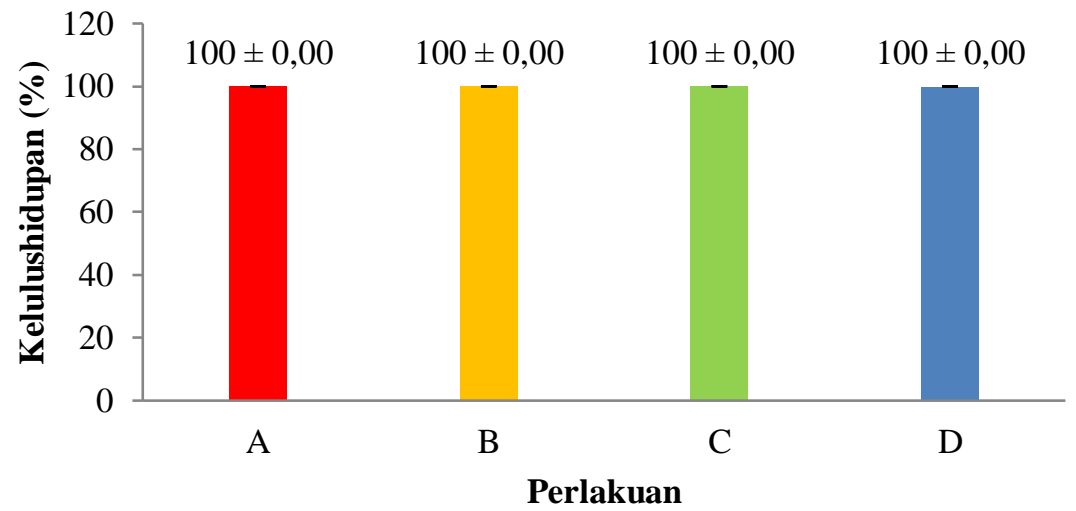

Gambar 5. Kelulushidupan ikan jelawat

Berdasarkan penelitian yang dilakukan selama 70 hari diperoleh hasil SR sebesar $100 \%$ pada setiap perlakuan dikarenakan tidak ada ikan yang mengalami kematian. Hasil analisis sidik ragam (Anova) menunjukkan bahwa pemberian $\mathrm{rGH}$ pada ikan jelawat tidak berpengaruh nyata terhadap kelulushidupan ikan. Dari hasil penelitian yang telah dilakukan dapat disimpulkan bahwa lingkungan serta perlakuan pemberian pakan yang mengandung rGH dengan dosis berbeda tidak mengganggu tingkat kelangsungan hidup ikan jelawat.

\section{Laju Konversi Pakan (FCR)}

Hasil perhitungan laju konversi pakan ikan jelawat lebih jelasnya dapat dilihat pada Gambar 6. 


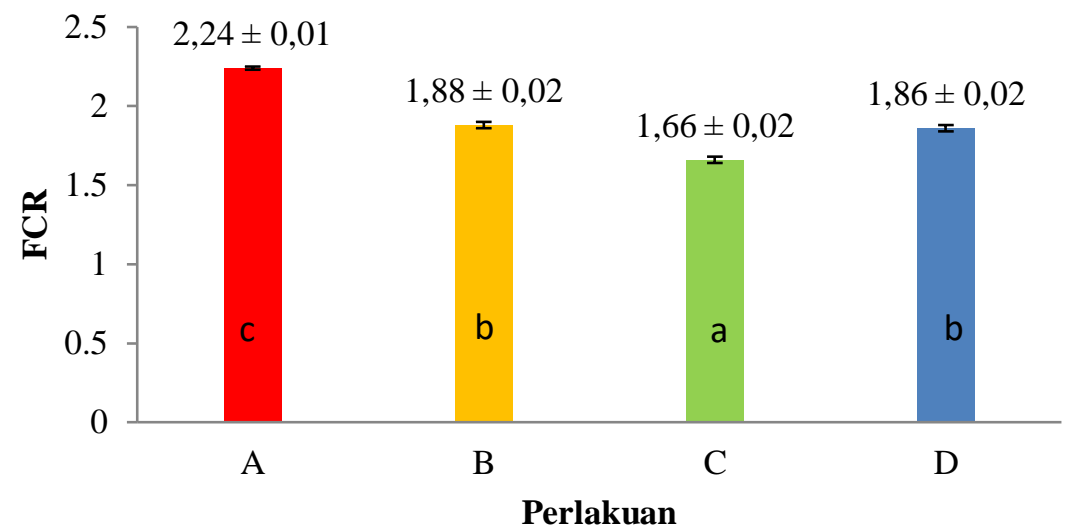

Keterangan: huruf kecil yang sama pada histogram menunjukkan perlakuan tidak berbeda nyata Gambar 6. Laju konversi pakan (FCR) ikan jelawat

Hasil penelitian menunjukkan bahwa laju konversi pakan ikan jelawat yang diberi penambahan $\mathrm{rGH}$ dengan dosis yang berbeda didapatkan nilai terbaik pada perlakuan $\mathrm{C}$ yaitu $1,66 \pm 0,22$, kemudian diikuti perlakuan $\mathrm{D}(1,86 \pm$ $0,02)$, perlakuan $\mathrm{B}(1,88 \pm 0,02)$, dan yang terendah pada perlakuan A $(2,24$ $\pm 0,01)$. Hasil analisis sidik ragam (Anova) menunjukkan bahwa pemberian rGH pada ikan jelawat berpengaruh nyata terhadap pertumbuhan ikan.

Pakan yang mengandung rGH diduga dapat dicerna lebih baik oleh sistem pencernaan dengan bantuan enzim yang merubah senyawa komplek menjadi senyawa sederhana dengan lebih singkat, sehingga ikan mampu memanfaatkan pakan dengan optimal. rGH yang masuk bersamaan dengan pakan diduga terlindungi oleh kuning telur untuk menghindari degradasi yang disebabkan oleh asam lambung dan akan terserap dengan baik ketika berada di usus (Ihsanudin et al, 2014). Pemberian rGH mampu meningkatkan nafsu makan, sintesis protein, dan konversi pakan.

Perlakuan $\mathrm{C}$ merupakan dosis yang efektif untuk menurunkan laju konversi pakan ikan jelawat dikarenakan penyerapan nutrisi pada pakan yang optimal. Sedangkan pada perlakuan B masih belum dapat menekan FCR secara optimal sehingga nilai FCR masih tinggi. Pada perlakuan D nilai FCR lebih tinggi dibandingkan perlakuan $\mathrm{C}$ tetapi tidak berbeda nyata dengan perlakuan B. Hal ini dikarenakan penyerapan nutrisi pakan pada perlakuan D terhambat karena adanya negative feedback atau sifat antagonistik sehingga berpengaruh terhadap laju konversi pakan ikan jelawat.

\section{Retensi Protein}

Hasil perhitungan retensi protein ikan jelawat lebih jelasnya dapat dilihat pada Gambar 7. 


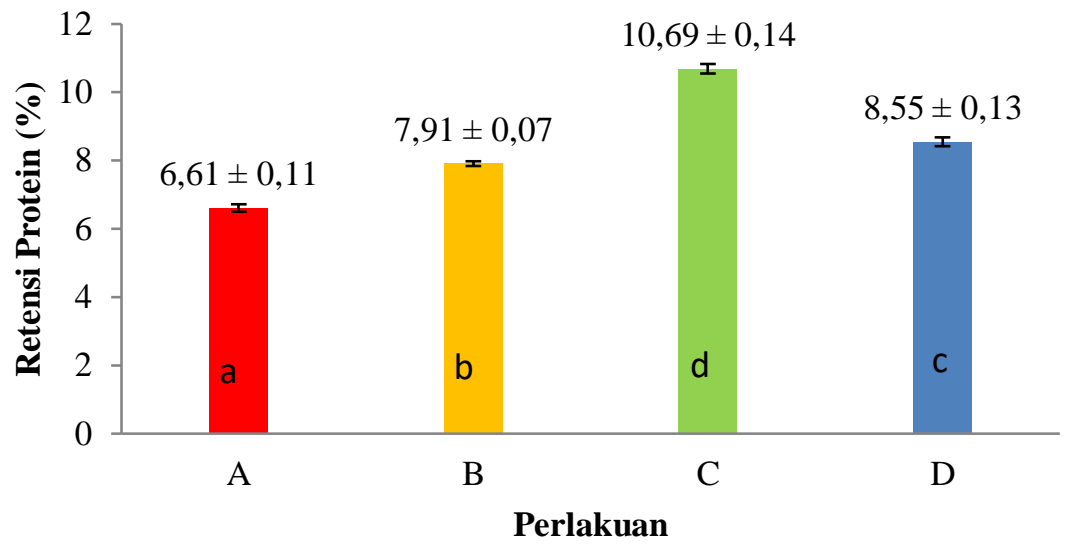

Keterangan: huruf kecil yang sama pada histogram menunjukkan perlakuan tidak berbeda nyata Gambar 7. Retensi protein ikan jelawat

Nilai rata-rata retensi protein berkisar antara 6,61 - 10,69\%. Retensi protein tertinggi terdapat pada perlakuan C (10,69 $\pm 0,14 \%)$, kemudian diikuti oleh perlakuan $\mathrm{D}$ $(8,55 \pm 0,13 \%)$, perlakuan B $(7,91 \pm$ $0,07 \%)$, dan perlakuan A $(6,61 \pm$ $0,11 \%)$. Hasil analisis sidik ragam (Anova) menunjukkan bahwa pemberian rGH pada ikan jelawat berpengaruh nyata terhadap pertumbuhan ikan.

Ikan yang diberi perlakuan $\mathrm{GH}$ dari luar (eksogen) memiliki kemampuan lebih besar untuk mencerna makanan, menyerap nutrisi, dan mengkonversi lebih besar proporsi makanan untuk membentuk komposisi tubuh ikan. Perlakuan C merupakan dosis yang efektif sehingga ikan jelawat dapat mencerna makanan dan menyerap nutrisi dalam pakan dengan lebih baik dan tingkat konversi makanan menjadi komposisi tubuh ikan juga semakin tinggi. Sedangkan pada perlakuan B masih belum seoptimal perlakuan $\mathrm{C}$ dalam mencerna, menyerap, dan mengkonversi makanan menjadi komposisi tubuh lebih baik. Nilai retensi protein pada perlakuan D menurun, hal ini dikarenakan pada perlakuan D memiliki sifat antagonistik.

Kualitas Air

Hasil pengukuran kualitas air selama pemeliharaan dapat dilihat pada Tabel 1.

\begin{tabular}{ccc}
\hline Parameter & $\begin{array}{c}\text { Hasil } \\
\text { Pengamatan }\end{array}$ & $\begin{array}{c}\text { Nilai } \\
\text { Optimal }\end{array}$ \\
\hline Suhu $\left({ }^{\circ} \mathrm{C}\right)$ & $27-28$ & $25-32^{*}$ \\
$\mathrm{pH}$ & $7-8$ & $6,5-9,5^{* *}$ \\
DO (mg/l) & $4,10-4,86$ & $3-6^{* * *}$ \\
\hline Sumber: * Rusnah (2004) & \\
**Boyd (1979) & \\
*** Puslitbangkan (1992) &
\end{tabular}

Suhu pada penelitian ini yaitu $27-28^{\circ} \mathrm{C}$ menunjukkan bahwa suhu air pada penelitian ini sudah layak untuk pertumbuhan ikan jelawat. Hasil pengukuran $\mathrm{pH}$ selama penelitian yaitu 7 - 8 dan merupakan kisaran $\mathrm{pH}$ yang sesuai untuk pertumbuhan ikan jelawat menurut Boyd (1979). Kandungan oksigen terlarut (DO) selama penelitian berkisar antara 4,10 - 4,86 mg/l sudah mencukupi kebutuhan ikan jelawat karena kisaran oksigen terlarut yang baik untuk pertumbuhan ikan jelawat 
antara 3 - $6 \mathrm{mg} / \mathrm{l}$ (Puslitbangkan, 1992).

\section{Kesimpulan dan Saran}

Pemberian rGH pada pakan buatan berpengaruh nyata terhadap pertumbuh-an, FCR, dan retensi protein tetapi tidak berpengaruh nyata terhadap kelulus-hidupan ikan jelawat. Dosis rGH sebanyak $2 \mathrm{mg} / \mathrm{kg}$ pakan merupakan dosis yang paling optimum untuk pertumbuhan ikan jelawat.

Pembudidaya dapat memberikan dosis $\mathrm{rGH} 2 \mathrm{mg} / \mathrm{kg}$ pakan pada pakan benih ikan jelawat, sehingga dapat meningkat-kan pertumbuhan benih ikan jelawat dan perlu dilakukan penelitian lanjutan mengenai pemanfaatan rGH pada skala budidaya yang lebih besar dan perlu dilakukan penelitian lanjutan mengenai pengaruh pemberian $\mathrm{rGH}$ sampai umur panen.

\section{Daftar Pustaka}

Abrar, M.Z., Edison, dan Sumarto. 2015. Profil asam amino ikan jelawat (Leptobarbus hoevenii) berdasarkan perbedaan umur panen. Jurnal Online Mahasiswa, 1-10.

Boyd, C.T. 1979. Water Quality in Warmwater Fish Pond. Auburn University Press, Alabama. 359 hal.

Cavari, B., B. Funkenstein, T.T. Chen, L.I. Gonzales-Villasenor, dan M. Schartl. 1993. Effect of Growth Hormone on the Growth Rate of the Gilthead Seabream (Sparus aurata), and use of Different Constructs for the
Production of Transgenic Fish. Aquaculture, 111(1-4): 189-197.

Farahiyah, I.J., A.R.Z. Abidin, A. Ahmad, dan H.K. Wong. 2017. Optimum Protein Requirement for the Growth of Jelawat Fish (Leptobarbus hoevenii). Mal.J. Anim.Sci, 20(2): 39-46.

Ihsanudin, I., S. Rejeki, dan T. Yuniarti. 2014. Pengaruh Pemberian Rekombinan Hormon Pertumbuhan (rGH) melalui Metode Oral dengan Interval Waktu yang Berbeda terhadap Pertumbuhan dan Kelulushidupan Benih Ikan Nila Larasati (Oreochromis niloticus). Journal of Aquaculture Management and Technology, 3(2): 94-102.

McLean, E., E.M. Donaldson, E. Teskeredzic, dan L.M. Souza. 1993. Growth Enhancement Following Dietary Delivery of Recombinant Porcine Somastotropin to Diploid and Triploid of Coho Salmon (Oncorhynchus kisutch). Fish Physiology Biochemistry, 11(1-6): 363-369.

Moriyama, S. dan H. Kawauchi. 1990. Growth Stimulation of Juvenile Salmonids by Immersion in Recombinant Salmon Growth Hormone. Nippon Suisan Gakkaishi, 56(1): 31-34.

Permana, A., A. Priyadi, R. Ginanjar, W. Hadie, dan Alimuddin. 2015. Pemberian Rekombinan Hormon Pertumbuhan Ikan Kerapu Kertang rEIGH secara Oral melalui Pakan Alami pada Benih Ikan Botia (Chromobotia macracanthus Bleeker, 1852). Prosiding Forum Inovasi Teknologi Akuakultur 2015, 303-309.

Puslitbangkan. 1992. Teknik Pembesaran Ikan Jelawat 
(Leptobarbus hoevenii Blkr) Secara Terkontrol. Departemen Pertanian, Badan Litbang Pertanian, Jakarta. 11 hal.

Putra, A.W., F. Basuki, dan T. Yuniarti. 2016. Pengaruh Penambahan Recombinant Growth Hormone ( $\mathrm{rGH})$ pada Pakan dengan Kadar Protein Tinggi terhadap Pertumbuhan dan tingkat Kelulushidupan Benih Ikan Gurame (Osphronemus gouramy). Journal of Aquaculture Management and Technology, 5(1): 17-25.

Rousseau, K. dan S. Dufour. 2007. Comparative Aspects of $\mathrm{GH}$ and Metabolic Regulation in Lower Vertebrates. Neuroendocrinology, 86(3): 165-174.

Rusnah. 2004. Pemanfaatan Limbah Kelapa Sawit (Solid) Sebagai Sumber Bahan Penyusunan Pakan Ikan Jelawat (Leptobarbus hoevenii Blkr). FPIK UMP, Pontianak. 57 hal.

Rusliadi, I. Putra, dan Syafriyandi. 2015. Pemeliharaan Benih Ikan Jelawat (Leptobarbus hoeveni Blkr) dengan Padat Tebar yang Berbeda pada Sistem Resirkulasi dan Akuaponik. Berkala Perikanan Terubuk, 43(2): 1-13.

Sakamoto, T., B.S. Shepherd, S.S. Madsen, R.S. Nishioka, K. Siharath, N.H. Richman, H.A. Bern, dan E.G. Grau. 1997. Osmoregulatory Actions of Growth Hormone and Prolactin in an Advanced Teleost. Gen Comp Endocrinol, 106(1): 95-101.

Yada, T., M. Nagae, S. Moriyama, dan T. Azuma. 1999. Effects of Prolactin and Growth Hormone on Plasma Immunoglobulin M Levels of Hypophysectomized Rainbow
Trout, Oncorhynchus mykiss. General Comparative Endocrinology. 115(1): 46-52. 
